\title{
EAGER EXSPECTATION DAN MOTIVASI MAHASISWA JURUSAN KOMUNIKASI DAN PENYIARAN ISLAM IAIN SALATIGA
}

\author{
Mukti Ali \\ Dosen Komunikasi dan Penyiaran Islam IAIN Salatiga \\ mukti1975@yahoo.co.id
}

\begin{abstract}
This article reveals about self motivation of KPI Student and study on new courses, both in psychological and social and social anthropologist confronting a range of very different situations. The psychological and social situation diversity and social anthropologist of KPI students is closely related to motivation and expectation which is varied. There is also the motivation from student to fulfill the knowledge of the world of communications and broadcasting which is related with the educational background of his secondary education, or he wants to continue his hobby in the broadcasting world. Dealing with the eager expectation or the big dream of KPI Student is divided into some expectation; The hope dealing with the learning process and supporting material from the learning process, and the expectation of their future after graduating from this department as a Bachelor of communication and broadcasting connected with employment chance the expectation in the process of teaching or educating for example, most students of KPI IAIN Salatiga needs some facilitation dealing with communications technology and the broadcasting technology such as, cameras, handy camp, and radio station.
\end{abstract}

Keyword: Eager Expectation, Motivation, Student of KPI

\begin{abstract}
Abstrak
Artikel mengungkapkan fokus pada bagaimana motivasi diri mahasiswa di Jurusan baru KPI IAIN Salatiga. Beberapa alasan yang dijadikan dasar mahasiswa adalah diantaranya yang penting kuliah, tidak penting program apa yang diambil, ada juga untuk pemenuhan pengetahuan tentang dunia komunikasi dan penyiaran untuk meneruskan hobinya dalam dunia penyiaran pasca jurusan SMK. Mengenai eager expectation mahasiswa KPI IAIN Salatiga, terbagi pada beberapa pengharapan; yaitu pengharapan dari proses dan pembelajaran sampai materi pendukung dari proses pembelajaran tersebut, misalnya peralatan-peralatan yang berkaitan dengan teknologi komunikasi dan teknologi penyiaran, seperti kamera, handycamp, statsiun radio. Mampu memberikan kualifikasi ilmu sehingga harapan masa depan mereka pasca lulus dengan menjadi sarjana komunikasi dan penyiaran dapat menghadapi tatangan di dunia kerja.
\end{abstract}

Kata Kunci: Eager Expectation, Motivasi, Mahasiswa KPI

\section{Pendahuluan}

Setiap lembaga atau institusi ingin selalu meningkatkan kualitas kelembagaan atau institusinya, baik lembaga pemerintah, sosial, keagamaan, ataupun lembaga lainnya yang secara terus menerus melakukan perbaikan dan peningkatan-peningkatan sesuai dengan warna dan karakter kinerja lembaga tersebut, baik dalam bidang pelayanan, kualitas kompetensi akademik, dan perluasan rumpun disiplin keilmuan, sampai pada 
out put kelulusannya yang akan digunakan oleh masyarakat. Pembukaan dan pelaksanaan Program Sarjana Komunikasi dan Penyiaran Islam (KPI) di Institut Agama Islam Negeri Salatiga merupakan bagian dari peningkatan lembaga yang memiliki potensi besar untuk terus berlanjut dan berkembang sesuai kebutuhan masyarakat. Untuk itu dalam memacu tingkat perkembangan dalam memenuhi kebutuhan berbagai pihak terhadap pendidikan secara optimal, diperlukan pengembangan IAIN Salatiga salah satunya yaitu pembukaan Jurusan Komunikasi dan Penyiaran Islam (KPI).

Jurusan Komunikasi dan Penyiaran Islam (KPI) sebagai institusi yang baru dibuka pada tahun 2013 telah memiliki sejumlah mahasiswa baru berjumlah 27 orang pada tahun yang sama. Secara teoritis maka semuanya berada dalam keberadaan yang 'tidak menentu' dalam menapaki keberlangsungannya. Tidak terkecuali pada mahasiswa Jurusan KPI yang sedang menapaki dunia baru, akan banyak kekhawatiran, rasa tidak yakin, ketidakjelasan lulusan, serta harapan yang ada dan motivasi mereka menjadi mahasiswa KPI. Menapaki dunia baru dalam hal apapun seakan tidak menjanjikan apaapa, dunia baru dirasa hanya menyajikan kekhawatiran, dan berbagai macam ujian. Kesemuanya wajar terjadi, tantangan, permasalahan akan selalu hadir sejalan dengan mengalirnya perjalanan dan perputaran roda kehidupan.

Penyelenggaraan Jurusan KPI di IAIN Salatiga dapat mempercepat pengadaan tenaga-tenaga ahli yang dibutuhkan oleh lembaga-lembaga pemerintah dan lembaga kemasyarakatan baik formal maupun nonformal yang terbingkai dalam era globalisasi. Pengadaan tenaga-tenaga ahli dan profesional tersebut dapat meningkatkan kualitas pembangunan sumber daya manusia terlebih dengan adanya penerapan otonomi daerah. Diharapkan di berbagai daerah dapat bersaing dengan wilayah lain yang pada gilirannya akan mendorong terbentuknya masyarakat yang mampu mengembangkan pembangunan di daerahnya.

Upaya IAIN Salatiga membuka Jurusan KPI dimaksudkan untuk turut memenuhi kebutuhan daerah dan pembangunan nasional, menyiapkan sumber daya manusia yang berkualitas, beriman, bertakwa, bermoral, cerdas, terampil, profesional, dan berdaya saing tinggi dalam bidang ilmu pengetahuan dan teknologi. Oleh karena itu, tenaga kerja yang menguasai bidang penyiaran dibutuhkan dalam rangka memenuhi lapangan kerja di berbagai sektor media komunikasi. Dalam kontek media komunikasi, prediksi kebutuhan sumber daya manusia yang kompeten dalam bidang penyiaran di Jawa Tengah antara lain dapat dilihat dari jumlah kebutuhan tenaga penyiaran yang 
diperlukan oleh lembaga-lembaga penyiaran baik media cetak maupun elektronik yang tersebar di belahan bumi ini.

Jurusan KPI IAIN Salatiga memiliki visi; Unggul dalam pengkajian dan pengembangan ilmu-ilmu komunikasi dan penyiaran yang berparadigma Islam. Sementara misinya; Pertama, menyelenggarakan pendidikan akademik dalam bidang komunikasi dan penyiaran Islam untuk membentuk sarjana yang berkualitas, profesional dan berakhlak mulia; Kedua, mengembangkan penelitian di bidang komunikasi dan penyiaran Islam; Ketiga, meningkatkan peran serta pada pengabdian masyarakat dalam aktivitas dakwah; Keempat, memperluas jaringan kerja sama dengan berbagai pihak untuk mengoptimalkan Tri dharma Perguruan Tinggi; Kelima, menyelenggarakan pengabdian pada masyarakat dengan mendorong kemauan dan meningkatkan kemampuan tenaga dakwah untuk mengamalkan ilmu pengetahuan dan keterampilan bagi kehidupan masyarakat baik di bidang dakwah, maupun bidang-bidang kehidupan sosial secara umum.

Peningkatan kualitas sumber daya di lingkungan dinas dan badan terkait, khususnya di bidang komunikasi dan penyiaran Islam menjadi suatu keharusan. Oleh karena itu, pembukaan Program Sarjana KPI IAIN Salatiga diharapkan menjadi salah satu solusi untuk meningkatkan kualitas sumber daya manusia, baik di bidang ilmu komunikasi dan kepenyiaran Islam. Uraian ini menunjukkan bahwa pembukaan Jurusan KPI IAIN Salatiga diharapkan dapat terus berlanjut dan maju.

Selain itu, Jurusan KPI pada IAIN Salatiga diselenggarakan sebagai upaya untuk merespon perkembangan ilmu pengetahuan dan teknologi yang semakin meningkat di era revolusi global, sehingga kehidupan manusia di masa depan akan dihadapkan pada berbagai permasalahan yang semakin canggih. Era globalisasi ditandai dengan adanya keterbukaan yang mengandung berbagai tantangan dan peluang menuntut sumber daya yang berkualitas, yaitu beriman, bertaqwa, cerdas dan profesional sehingga dapat bermanfaat dan bersaing di dalam pergaulan kehidupan bangsa di dunia. Mewujudkan sumber daya manusia, masyarakat yang semakin membutuhkan tenaga-tenaga terdidik yang berorientasi pada keilmuan dan profesional dalam bidang keislaman dan pengajarannya. Perkembangan masyarakat yang berada dalam proses globalisasiinformasi dan hubungan internasional.

Upaya untuk mengantisipasi dan menjawab secara nyata terhadap perkembangan masyarakat yang akseleratif tersebut, IAIN memperhatikan secara seksama pentingnya 
realisasi pembukaan program sarjana umum, yakni Jurusan KPI. Pembukaan jurusan ini diharapkan dapat menjadi mediasi dan komunikasi akademik dalam memahami, menjelaskan, merumuskan, sekaligus menerapkan perkembangan di bidang keilmuan sosial dan pengajarannya secara nyata.

Tujuan jurusan KPI IAIN Salatiga, adalah; Pertama, menguasai, mengembangkan, dan mengamalkan ilmu KPI dijiwai oleh nilai-nilai Islam yang relevan dengan kebutuhan pembangunan bangsa; Kedua, melahirkan sarjana yang profesional dalam bidang komunikasi dan penyiaran Islam; Ketiga, melahirkan sarjana yang memiliki wawasan dan keterampilan dalam bidang pers, penyiaran, dan retorika; Keempat, menjalin kerjasama dengan berbagai pihak untuk mengoptimalkan tridharma perguruan tinggi.

\section{Permasalahan}

Fokus masalah ini dapat diuraikan sebagai berikut; (a) Bagaimana motivasi mahasiswa masuk di KPI IAIN Salatiga? (b) Bagaimana Eager Expectation Mahasiswa KPI IAIN Salatiga? (c) Bagaimana sikap mahasiswa KPI IAIN Salatiga antara motivasi dan Eager Expectation?

\section{Eager Exspectation dan Motivasi}

Peranan manusia dalam mencapai tujuan tersebut sangat penting dalam pencapaian tujuan organisasi. Untuk menggerakkan manusia agar sesuai dengan yang dikehendaki organisasi, maka haruslah dipahami motivasi manusia bekerja pada suatu organisasi, karena motivasi inilah yang menentukan perilaku orang-orang untuk bekerja atau dengan kata lain perilaku merupakan cerminan yang paling sederhana dari motivasi.Istilah kata eager artinya digunakan untuk keinginan positif dimana hal baik atau menyenangkan akan terjadi, sedangkan kata expectation artinya adalah pengharapan. Jadi Eager Expectation merupakan hasrat dan harapan seseorang dalam melakukan sesuatu atau bersikap sesuatu. (Syamsuri, 2010:37)

Teori harapan kadang disebut teori ekspektansi atau expectancy theory of motivation dikemukakan oleh Victor Vroom pada tahun 1964. Vroom lebih menekankan pada faktor hasil (outcomes), ketimbang kebutuhan (needs) seperti yang dikemukakan oleh Maslow and Herzberg (Stephen, 2008:253). 
Motivasi berasal dari kata latin yaitu Movere yang berarti dorongan atau mengerakan. Menurut Djamarah mendefiniskan motivasi sebagai perubahan energi dalam diri seseorang yang ditandai dengan munculnya feelling dan didahului dengan tanggapan terhadap adanya tujuan. Perubahan energi dalam diri seseorang itu berbentuk suatu aktivitas nyata berupa kegiatan fisik. Karena seseorang mempunyai tujuan tertentu dan aktivitasnya, maka seseorang mempunyai motivasi yang kuat untuk mencapainya (Djamarah, 2008:148)

\section{Metodologi Penelitian}

Penelitian ini menggunakan pendekatan kualitatif diskriptif yaitu penelitian yang menghasilkan dan mengolah data yang sifatnya deskriptif, untuk menggambarkan, mengungkap, dan menjelaskan motivasi mahasiswa masyuk di Jurusan Komunikasi dan Penyiaran Islam IAIN Salatiga serta eager expectation mahasiswa KPI IAIN Salatiga. Penelitian ini dilakukan pada mahasiswa KPI Fakultas Dakwah IAIN Salatiga angkatan pertama, selama enam bulan.

Penetapan subyek penelitian atau informan dipilih subyek pertama sebagai informan kunci yaitu informan yang didasarkan pertimbangan tertentu memenuhi syarat sebagai informan yang sangat mengetahui aspek-aspek permasalahan yang diteliti, Subyek penelitian sebagai informan dalam penelitian ini terdiri dari seluruh mahasiswa KPI Fakultas Dakwah IAIN Salatiga angkatan pertama. Teknik pengumpulan data yang dipakai dalam penelitian ini adalah observasi partisipasi, wawancara mendalam (in-depth interviewing) dan teknik dokumentasi.

\section{Motivasi Mahasiswa KPI IAIN Salatiga}

Menurut Syaiful Bahri Djamarah (2008:149), motivasi berasal dari dalam diri pribadi seseorang disebut motivasi intrinsik, yaitu motif-motif yang menjadi aktif atau berfungsinya tidak perlu dirangsang dari luar. Hal ini dikarenakan di dalam diri setiap individu sudah ada dorongan untuk melakukan sesuatu. Sedangkan motivasi yang berasal dari luar diri seseorang disebut motivasi ekstrinsik, yaitu motif-motif yang aktif dan berfungsi karena adanya perangsang dari luar. Ada berbagai macam motivasi dan pandangan oleh empat belas mahasiswa KPI sebagaimana dijelaskan sebagai berikut; ANK (1) yakin bahwa Jurusan KPI ini dapat berkembang pesat walau masuk kategori jurusan baru di IAIN Salatiga. ANK sebagai mahasiswa angkatan pertama sangat 
menyadari kalau jurusan tempat kuliahnya itu akan dipandang sebelah mata oleh jurusan lain. Tapi ANK menganggap hal itu adalah suatu kewajaran.

Sementara motivasi AWU (2) dengan cara orang tua selalu mendidik, menasehati, menyayangi, serta membiayai. Terlihat jelas motivasi orang tua AWU pada dunia pendidikan. Orang tuanya selalu menasehati, bahwa; "Yang penting sekolah dulu, cari ilmu dulu, tidak usah memikirkan nanti jadi apa. Karena semua itu sudah ada yang mengatur". Itulah yang menjadi motivasi AWU dalam dunia pendidikan. Orang tua AWU terus mendesak dan menasehati saya; "kamu sekolah di mana, di jurusan apa, itu bukan masalah, apa semua orang yang kuliah di pendidikan pasti jadi guru, apa semua yang sekolah di lain Jurusan pendidikan tidak bisa jadi guru, Allah memilihkan kamu sekolah di IAIN, di Jurusan KPI, kalau memang kamu ditakdirkan menjadi Guru pasti nanti ada jalannya, yang penting sekarang kamu sekolah dulu". Dan yang paling membuat AWU termotivasi adalah perkataan ibunya; "Sekolah ya nang sekolah agama tho le, etok donyo lan agamane, nang Salatiga kono wae malah cedak". Menurut AWU, Komunikasi dan Penyiaran Islam adalah jurusan yang paling baik, dan tepat untuk dirinya.

Dalam motivasi belajar AR (3) dalam hati bertanya-tanya "apakah masih ada ya perguruan tinggi yang masih buka pendaftaran?" pertanyaan itu terjawab dengan menemukan IAIN Salatiga masih membuka pendaftaran. AR melihat jurusan baru yaitu KPI, yang kebetulan sebelumnya saya melihat informasi di internet bahwa KPI itu adalah Broadcasting dan Jurnalistik. Pada saat itu AR sangat mantap dan senang melihat di IAIN Salatiga ada KPI. Selain KPI itu tidak jauh atau melenceng dari apa yang disukainya yaitu teknologi, selain itu IAIN Salatiga itu biaya pendidikannya murah.

Keinginan orang tua AC (4) agar anak-anaknya selalu menuntut ilmu setinggitingginya dan sebaik-baiknya. Karena mereka ingin agar anak-anak mereka lebih baik dari mereka. Bapak dan Ibu AC selalu berkata "Bapak sama ibu sudah tidak pintar, kalian tidak boleh seperti ini, kalian harus lebih baik dari kami. Maka bersungguhsungguhlah kamu untuk belajar, agar kamu menjadi orang yang sesungguhnya atau sukses. Kalian tidak boleh seperti Bapak dan Ibu! kata-kata inilah yang menyemangati AC kembali bangkit dan terus bangkit untuk belajar. AC harus berusaha memberikan yang terbaik, dengan kuliah dan belajar sungguh-sungguh. Semoga mendapatkan yang terbaik. Pengalaman kegagalan AC untuk kuliah di beberapa perguruan tinggi untuk berhenti dulu dan melanjutkan kuliah pada tahun depan. Namun, ketika AC 
membicarakan hal tersebut pada keluarga dan diberi motivasi dan berbagai macam pertimbangan oleh keluarganya, selain karena keadaan ekonomi keluarga saya yang kurang mendukung, akhirnya AC mendaftarkan diri ke IAIN Salatiga. Dan langsung mengambil KPI saja. Karena dengan berkaitan dengan komunikasi seperti tekhnologi yang semakin berkembang dan memang cocok untuk saat ini. Selain itu di semua Perguruan Tinggi khususnya PTS belum tentu setiap PTS dalam fakultas tersebut ada Jurusan KPI. AC mengambil Progam Studi Komunikasi dan Penyiaran Islam karena ia ingin belajar lebih tentang Ilmu Komunikasi dan ingin lebih mengetahui dan belajar yang berkaitan dengan teknologi, dan apabila nanti ada pilihan jurusan misal memilih jurusan Dakwah atau Broadcasting ia akan memilih Broadcasting. Menurut AC Program Studi Komunikasi dan Penyiaran Islam walaupun Jurusan baru tetapi AC tetap berfikir positif atau positif thinking, optimis walaupun Jurusan baru tapi suatu saat pasti KPI akan sama statusnya dan kwalitasnya dengan Jurusan lainnya. Meskipun Program Studi baru tetapi mahasiswa KPI berusa untuk menjadi yang terbaik minimal di antara Jurusan baru lainnya. Untuk menghadapi masa depan, sebagai seorang lulusan Komunikasi dan Penyiaran Islam AC optrimist bahawa ia bisa menjadi orang yang sesungguhnya. AC ingin suatu saat nanti memiliki sebuah usaha, misal seperti percetakan, photo studio, ataupun yang sejenisnya. Sebagai seorang mahasiswa Komunikasi dan Penyiaran Islam seperti kata Bapak Mukti Ali, minimal harus bisa berbicara di depan publik. Dan AC ingin cepat pandai berbicara di depan publik tanpa grogi atau malu-malu.

Hingga pada suatu saat ARF (5) mendapat informasi tentang perpanjangan pendaftaran mahasiswa baru di IAIN Salatiga untuk Jurusan baru. ARF sadar itu adalah sebuah peluang, sebuah kesempatan kedua. Dan dengan kemantapan hati ARF memilih jurusan KPI. Lewat seorang gurunya yang membantu untuk membayar administrasi biaya pendaftaran dan daftar ulang. ARF mulai menjalaninya menjadi seorang mahasiswi di IAIN Salatiga. Meski dengan kondisi keluarga yang seperti itu, ia tetap mencoba bersabar dan tetap semangat untuk menempuh segala rintangan yang ada. Segalanya perlu mimpi, dan itu aku tunjukan dari betapa kerasnya ARF ingin berkuliah, bagaimanapun caci dan maki orang-orang. Segala impian itu selalu ditulisnya dalam sebuah buku kecil.

Memang latarbelakang keluarga AMP (6) sangat kental dengan dunia tulis menulis, koran, dan tentunya kehidupan jurnalis. Sering AMP diajak oleh ibunya untuk 
menemani bekerja. Jadi AMP amat bersemangat untuk mengambil kuliah pada Jurusan Komunikasi. Namun AMP beranggapan semangat saja tidak cukup, namun passion yang membuatnya harus berkuliah pada jurusan komunikasi. Idealis memang, namun ia tidak mau berada pada keadaan yang dipaksakan. Sejujurnya saja, AMP setelah lulus dari SMU berniat mengambil kuliah di UGM jurusan komunikasi. Menurut pandangannya, Komunikasi UGM adalah tempat yang paling tepat untuk kuliah. Karena mampu mencetak alumni yang berkualitas, walau berbagai test yang diikuti gagal. Kegagalan itu menumbuhkan motivasi untuk berkuliah di KPI IAIN Salatiga.

Diterimanya BS (7) di IAIN Salatiga pada jurusan KPI yang merupakan jurusan baru di IAIN Salatiga merupakan sebuah kegembiraan sekaligus sebuah tantangan. Karena sebuah program baru selalu dianggap remeh oleh sebagian orang, karena minimnya prestasi yang diraih dan selalu dianggap sebagai anak baru. Namun bagi BS bukan masalah baru atau lamanya sebuah program studi yang menentukan baik buruknya sebuah jurusan. Juga bukan tergantung dari banyaknya prestasi yang diraih oleh sebuah jurusan. Karena semua hal itu diraih di masa lalu dan yang kita hadapi adalah masa sekarang. Jadi menurut BS yang menentukan kualitas suatu jurusan adalah mahasiswa yang ada di dalamnya. Semakin berkualitas mahasiswa yang ada di dalamnya, maka akan semakin banyak prestasi yang akan diraih dan tidak akan dipandang sebelah mata lagi oleh orang lain. Jurusan KPI akan memberikan banyak hal. Komunikasi adalah jurusan yang penting, karena setiap hari kita berkomunikasi, setiap hari kita berinteraksi menggunakan komunikasi. Jadi jurusan ini tidak bisa dianggap remeh. Apalagi program studi ini berdasarkan agama Islam. Namun tidak hanya mempelajarinya saja namun juga menerapkannya dalam kehidupan. Jadi dalam mempelajari jurusan ini tidak hanya dibutuhkan teori saja melainkan harus disertai dengan praktik. Kalau kita hanya diberi teori tanpa penerapan. Apabila kita dihadapkan dengan dunia kerja, kita hanya akan tahu teorinya saja tanpa bisa menerapkan teori itu. Jadi teori dan praktik di sini sama-sama dibutuhkan. Teori dibutuhkan di kelas sedangkan praktik akan berguna untuk menghadapi dunia keras saat kita lulus nanti. Lulusan KPI kemungkinan nanti akan menghadapi dunia kerja yang berhubungan dengan penyiaran di bidang tv, radio, atau sebagai jurnalis. Apabila hanya dikasih teori tanpa ada pengenalan di bidang tersebut, maka sarjana komunikasi penyiaran hanya mengetahui teori tanpa tahu praktik lapangan yang berkaitan dengan alat-alat yang akan digunakan dalam dunia kerja tesebut. Melalui teori dan praktik seorang Sarjana KPI 
akan lebih matang dan siap untuk menghadapi duni kerja. Namun untuk mewujudka itu butuh kerja keras dari pihak mahasiswa maupun lembaga. Dari pihak lembaga dibutuhkan sarana yang menunjang kegiatan belajar mengajar. Sedangkan dari pihak mahasiswa dibutuhkan kerja keras untuk belajar dan memahami semua materi yang diberikan. Mahasiswa harus bersemangat menempuh pendidikan tersebut.

Dalam sistem pengasuhan ini, orang tua DA (8) tidak membeda-bedakan dalam mengasuh. Orang tua menyuruh belajar dan terus belajar agar menjadi orang sukses di masa depan. Motivasi orang tuanya mempunyai dua pilihan, yang pertama memilih sekolah dan yang kedua milih sepeda motor atau barang yang lain. Kalau milih sepeda motor, berarti sekolah harus berhenti dan harus cari uang dengan cara menjadi tukang ojek, begitu pula sebaliknya. Anak-anaknya memilih untuk sekolah dulu. KPI itu kelihatanya asyik, bisa saling berkomunikasi satu sama lain. Memang KPI itu hanya dipandang sebelah mata, tetapi baginya KPI itu sangat menyenangkan, apalagi orangorang yang mengelola jurusan itu. Bagi DA, "KPI itu love is a live."

Ternyata di balik kegagalan yang pernah DAS (9) alami tidak diterimanya di SMPTN BIDIKMISI, ternyata ada hikmah yang tidak pernah DAS duga yaitu ditawari untuk kuliah ditambah diberikannya beasiswa untuk melanjutkan kuliah di IAIN Salatiga dengan jurusan KPI. Saat ini DAS sudah mantap untuk belajar di KPI IAIN Salatiga dan akan menjalaninya dengan sebaik mungkin. Meskipun DAS juga merasa sedikit ragu dikarenakan KPI juga merupakan jurusan baru di IAIN Salatiga dan mungkin juga dibedakan dari jurusan-jurusan yang lain, dan yang pasti kalah dari KPI di universitas lain yang memang sudah berdiri sejak lama, terlebih dulu muncul dan berkualitas dengan akreditasi yang baik. Meskipun KPI merupakan jurusan baru di IAIN Salatiga, tapi DAS percaya lulusan KPI IAIN Salatiga tidak akan kalah kualitasnya dengan KPI di universitas-universitas lain, dan tentunya juga akan mendapatkan ilmu agama yang lebih untuk memperkuat kualitas keagamaannya. Selanjutnya DAS mencoba menjalani semua yang akan ditempuh di bangku perkuliahan IAIN Salatiga.

Kegagalan SBMPTN itu membuat MH (10) untuk mendaftar SPMB-PTAIN. MH memilih UIN dengan pilihan pertamanya mengambil jurusan Psikologi. Pilihan keduanya mengambil jurusan Ilmu Komunikasi, dengan hasil kurang beruntung dia gagal lagi di test masuk, dan akhirnya berniat untuk kuliah di kampus swasta. Selang beberapa lama saat ayah MH menyuruhnya untuk buka website IAIN Salatiga, dan 
ternyata IAIN Salatiga masih membuka penerimaan mahasiswa dan mahasiswi jalur mandiri. Kemudian $\mathrm{MH}$ mencoba untuk mendaftar dengan memilih tiga jurusan, pilihan pertama jurusan PAI, dengan alasan ingin menjadi guru, pilihan kedua jurusan Perbankan Syariah S1, karena agar dapat bekerja di perbankan seperti kakaknya yang bekerja di perbankan, dan jurusan yang terakhir MH memilih jurusan KPI. Motivasi MH mengambil KPI karena ia ingin pintar berbicara di media. Selain itu, MH ingin menggali bakat fotografinya yang telah diajarkan oleh kakak yang sama-sama dari jurusan komunikasi, tentunya dengan mendapatkan ilmu agama juga. Karena jurusan komunikasi adalah jurusan yang membuat banyak kreatifitas dan indra-indra seperti penglihatan dan pengucap saling interaksi satu sama yang lain.

Alasan MF (11) kuliah di IAIN Salatiga mengambil jurusan KPI ingin meneruskan jejak langkah perjuangan bapaknya sebagai pendakwah di desa. Mungkin kalau punya kesempatan MF bukan hanya ingin berdakwah di desa melainkan bisa berdakwah antar provinsi ataupun di media komunikasi seperti televisi maupun di radio-radio.

Motivasi MNA (12) seperti yang ia tuturkan; "Di situ saya mencari jurusan yang masih terkait dengan seni, karena saya menyadari bahwa saya tidak bisa dijauhkan dengan seni. Apapun itu, dengan seni hidup akan lebih indah. Kebetulan di tahun ini ada jurusan baru yang menurut saya masih terkait dengan seni, yaitu KPI. Alhamdulillah setelah melalui beberapa test akhirnya saya diterima pada Jurusan KPI. Di lain waktu saya masih ragu masuk pada Jurusan KPI ini, apalagi KPI merupakan jurusan baru. Setelah mendapat masukan dari beberapa saudara saya, saya menjadi yakin dan saya tidak lagi meragukan Jurusan KPI. Yang ada dalam benak saya, saya hanya ingin menambah ilmu dan ilmu entah nantinya ilmu tersebut digunakan atau tidak. Tetapi saya yakin bahwa di luar sana masih banyak yang membutuhkan lulusan KPI."

Motivasi kuliah PM (13), karena dorongan dari kakaknya selain keinginan sendiri untuk menjadi lebih baik dari apa yang ia punya sekarang. Secara pendidikan, PM berkeinginan lebih dari kakak-kakaknya dan menambah teman sebanyak-banyaknya, karena teman itu adalah segalanya, mereka bisa menghibur dan juga bisa memotivasi PM untuk menjadi lebih baik. Selain itu juga berkeinginan menambah ilmu, wawasan, pengalaman, dan belajar dari para dosen.

Sebelum menamatkan pendidikan dibangku sekolah dan selama menghadapi persiapan ujian nasional, KAS (14) sudah mengikuti try out seleksi bersama masuk 
perguruan tinggi negeri. Salah satu perguruan tinggi yang diikuti KAS adalah try out di UNS Solo, dengan mendapatkan rangking limapuluh besar dari sekian ratus peserta yang mengikuti program tersebut. Dari hasil tersebut KAS optimis bisa diterima pada ujian seleksi bersama masuk perguruan tinggi negeri yang sebenarnya. Segala macam usaha pun telah dilakukannya, seperti mengikuti les intensif persiapan menghadapi ujian seleksi bersama masuk perguruan tinggi negeri, akan tetapi saat pengumuman SNMPTN undangan telah diumumkan, ternyata KAS tidak lulus. Kemudian semangat baru kembali muncul dengan tidak pernah absen dari les intensif sebelumnya, sehingga pada akhirnya tibalah hari dimana seluruh calon mahasiswa mengikuti tes seleksi bersama masuk perguruan tinggi negeri pada tanggal 18 juni 2013 lalu. Dari pengumuman SBMPTN dengan pasrah dan hati yang berdebar KAS membuka pengumuman itu melalui media online, ternyata keberuntungan dan rejeki masih belum belum berpihak padanya. KAS harus gagal kedua kalinya untuk masuk di perguruan tinggi yang diinginkannya. Setelah berpikir, akhirnya KAS mengambil kuliah di Jurusan KPI IAIN Salatiga. Jadi alasan masuk IAIN Salatiga karena sudah tidak diterima di mana-mana, tetapi kemungkinan di tahun yang akan datanag dia akan kembali mencoba untuk mengikuti seleksi bersama masuk perguruan tinggi negeri.

\section{Eager Expectation Mahasiswa KPI IAIN Salatiga}

Carley. H. Dodd (1982:98), menjelaskan eager expectation atau harapan besar, di mana tahap ini orang tersebut merencanakan untuk memasuki kebudayaan kedua atau kebudayaan baru. Rencana tersebut dibuatnya dengan semangat pengharapan, walaupun pada perasaan was-was akan kemungkinan-kemungkinan situasi yang akan dihadapinya. Akan tetapi rasa optimisme dan semangat yang besar tadi lebih mendominasi pikirannya untuk terus menapaki dan melalui keinginanya.

Eager expectation atau harapan besar ANK dalam proses pembelajaran di Jurusan KPI IAIN Salatiga adalah suasana yang nyaman, tenang, dan sistem diskusi yang menarik, serta penugasan untuk presentasi yang diberikan oleh dosen didalamnya terdapat unsur-unsur yang dapat menggali kreatifitas mahasiswa dalam menyusun dan mempresentasikan tugas di kelas. Untuk media pengembangan bakat merasa membutuhkan sebuah studio atau laboratorium jurusan, yang di dalamnya terdapat peralatan yang dibutuhkan dalam pertelekomunikasian dan kepenyiaran, yang mendekati layaknya sebuah Production House (PH). Misalnya kamera, handicamp, dan 
lain-lain. Tetapi ANK pun menyadari untuk fasilitas tersebut belum begitu lengkap atau memadai untuk Jurusan KPI di IAIN Salatiga. Setelah lulus dari IAIN harapan ANK adalah ingin berusaha menerapkan ilmu yang didapatkan dari bangku kuliah di IAIN Salatiga maupun dunia kerja. ANK yakin bahwa lulusan KPI IAIN Salatiga akan menjadi orang yang berkualitas walaupun ia menyadari masih banyak kekurangan dalam praktik perkuliahan.

AWU berharap pembelajaran pada Jurusan KPI ditunjang dengan adanya studio atau laboratorium KPI, agar pembelajaran di KPI dapat maksimal. Setelah lulus dari KPI, ia berkeinginan bekerja di bidang yang sesuai dengan disiplin keilmuannya sebagai seorang yang terlibat di pertelevisian, dan mempunyai pemikiran untuk meneruskan cita-citanya dulu, yaitu sebagai guru, tentunya harus berusaha mewujudkan cita-cita tadi dengan sekuat tenaga

Harapan AR masuk di Jurusan Komunikasi dan Penyiaran Islam IAIN Salatiga agar ia tidak ketinggalan dalam era globalisasi, terutama perkembangan teknologi yang semakin canggih dan dapat mempelajari lebih dalam ilmu komunikasi seperti broadcasting, pembuatan video, jurnalistik, presenting. Selain itu, AR juga berharap dalam perkuliahannya sarana dan prasarana praktikum agar segera diadakan untuk kemajuan mahasiswa-mahasiswi KPI, dan agar menjadikan lulusan KPI yang handal dalam bidang broadcasting, pembuatan video, jurnalistik, presenting.

AC mengharapkan Jurusan KPI cepat diakui keberadaannya atau statusnya terakreditasi yang lebih baik. Walaupun jurusan baru untuk menunjukkan pada jurusan lainnya bahwa KPI itu ada dan AC tidak salah telah mengambil Jurusan KPI, ini bukanlah sebuah keterpaksaan, melainkan AC secara pribadi memiliki keinginan dan kemauan sendiri. AC berharap semoga sarana dan prasarana khususnya untuk Jurusan KPI disediakan dengan semaksimal mungkin. Misalnya dengan adanya laboratorium khusus untuk KPI seperti penyiaran radio atau yang sejenisnya, kamera handicame, laptop atau komputer editing video agar lebih menunjang kompetensinya. AC berharap semoga besok mahasiswa KPI dapat lulus bersama-sama tanpa ada yang tertingal sampai semester akhir.

Beranilah bermimpi, karena dengan bermimpi akan lebih bersemangat dan mempunyai tujuan hidup yang pasti. Lebih baik berani bermimpi dari pada tidak sama sekali. Inilah motivasi ARF dalam menjalankan kuliahnya. ARF kuliah di IAIN Salatiga dengan mengambil Jurusan KPI memiliki harapannya adalah mempunyai dan 
membentuk kepribadian islami dengan berbagai profesi di dunia kerja, misal menjadi ustadzah yang handal dalam bidang teknologi. Harapan lain dari ARF setelah lulus dari Jurusan KPI, yaitu menjadi seorang pendakwah ternama, sehingga bisa membanggakan orang tua, serta membuka jalan fikiran masyarakat menjadi lebih baik melalui tausiahtausiahnya. Serta mempunyai talenta di dunia komunikasi, seperti; broadcasting, jurnalistik, serta talenta-talenta yang lainya.

Apa yang diharapkan APM tidak jauh dari mahasiswa KPI IAIN Salatiga lainnya. Pembelajaran di Jurusan KPI harus banyak praktik. Praktik sangat penting untuk dapat mengembangkan skill, dan tentunya menambah pengalaman. Studi banding di jurusan yang sama pada kampus yang lebih maju agar dapat termotivasi. APM memacu kesungguhan belajarnya dengan cara menghapus semua pikiran buruk dan kemalasan. APM harus mempunyai target dalam belajar lulus sesuai dengan cepat. Harapannya setelah lulus dari KPI dapat menjadi anak yang berguna bagi keluarga dan orang-orang di sekitarnya dengan profesinya kelak.

BS selalu berfikir bahwa ia harus segera menyelesaikan pendidikannya sesuai dengan waktu yang telah direncanakan. Bagi BS, dalam keadaan sehat ia harus bersungguh-sungguh dalam belajar, karena belum tentu hari berikutnya diberi kesehatan, selagi orang tuanya masih diberi kesehatan juga. Kalau BS berhasil menyelesaikan pendidikan ini selagi mereka masih sehat, merekapun akan ikut merasakan kebahagiaan. Kebahagiaan orang tua akan tampak saat anaknya mampu menyelesaikan pendidikanya dengan nilai yang baik. Karena dengan itulah yang sanggup BS berikan kepada mereka ketika masih menempuh pendidikan. Untuk kelanjutan setelah menyelesaikan kuliah dengan bekerja yang sesuai keahliannya, misalnya dunia perfilman dan jurnalis, maka BS berharap dapat bekerja dan terlibat dalam bidang tersebut. Bagi BS, terlibat dalam penyiaran dan peliputan berita merupakan hal yang menarik dan penuh tantangan. Dapat memberikan informasi tentang perkembangan dunia, memberi wawasan kepada orang dan diri sendiri. Melalui komunikasi orang selalu berinteraksi dan saling bertukar pengetahuan. Jadi dengan komunikasi tidak akan kekurangan informasi apapun. BS berharap dengan ilmu ini akan mempermudahnya dalam mendapatkan pekerjaan.

DAS memiliki harapan bahwa proses perkuliahan di Jurusan KPI akan lebih efisien dan berkualitas bila ditunjang dengan fasilitas yang memadai, disamakan dengan jurusan lain yang sudah lama ada di IAIN Salatiga, mungkin salah satu fasilitas yang sesuai dengan jurusan komunikasi yaitu kamera. Kemudian yang kedua, DAS 
mengharapkan bisa memiliki studio untuk melakukan praktik Jurusan Komunikasi yang bergantung pada media, contoh kecil adalah studio penyiaran. Melalui media tersebut diharapkan KPI di IAIN Salatiga bisa maju dan berkembang sesuai dengan harapan. Harapan lain DAS adalah bisa mengamalkan ilmu-ilmu yang didapatkannya selama belajar di Jurusan Komunikasi dan Penyiaran Islam IAIN Salatiga dan menjadi orang yang berguna, baik di lingkungan keluarga maupun di lingkungan masyarakat, DAS juga dapat menyebarkan Islam melalui media dakwah, karena Jurusan Komunikasi dan Penyiaran Islam mempelajari tentang semua media komunikasi yang didasari oleh ilmu agama yang kuat. Dengan diajarkannya ilmu komunikasi tidak hanya menjadi pendakwah saja tetapi juga bisa menjadi penyiar radio, presenter di televisi, reporter, wartawan, untuk itu bagi DAS tidak perlu ragu menghadapi masa depan dengan menyandang sarjana KPI dan berhak mendapat pekerjaan yang layak sebagaimana mestinya.

Harapan besar MH dalam proses perkuliahan Jurusan Komunikasi dan Penyiaran Islam setidaknya harus dengan fasilitas yang memadai, misalnya fotografer yang harus mempunyai alat media jurnalis andalan yaitu kamera. Sesuai dengan jurusan Komunikasi, selain itu Jurusan KPI harus memiliki studio sebagai tempat praktik atas apa yang didapatkan dalam teori-teori. Selanjutnya $\mathrm{MH}$ berharap bahwa sebagai angkatan pertama, harus bisa menunjukan jika jurusan Komunikasi dan Penyiaran Islam tidak dipandang sebelah mata oleh jurusan-jurusan yang lain dengan membuat demo video bagaimana profil Komunikasi dan Penyiaran Islam dari IAIN Salatiga, agar adik-adik tingkat yang ingin memilih jurusan ini tidak ragu karena jurusan baru. Dengan adanya semua itu diharap bisa memajukan jurusan baru ini agar berkualitas.

Dengan masa tempuh kuliah selama empat tahun dan jika lulus $\mathrm{MH}$ akan mencari informasi apakah lulusan KPI dibutuhkan oleh TNI atau POLRI. Jika tidak ada, ia akan mendaftarkan diri ke Kemenag. Dan kemudian perusahaan BUMN yang meliputi perbankan, pegawai televisi dan yang lain adalah $\mathrm{MH}$ akan menyebarkan agama melalui dakwah.

Harapan MF mengambil jurusan Komunikasi dan Penyiaran Islam di IAIN Salatiga, dan setelah lulus adalah biasa berceramah di depan publik. Karena setelah lulus dari IAIN Salatiga pasti kemampuan dan wawasan akan bertambah. Jika diminta untuk berceramah tidak akan kebingungan lagi untuk mencari buku, karna sudah di simpan di memori otak. Kemudian yang diharapkan dalam pembelajaran adalah fasilitas yang 
harus memadai terutama Jurusan KPI, harus memiliki studio untuk melakukan aktifitas komunikasi pada media yang telah difasilitasi agar Komunikasi dan Penyiaran Islam IAIN Salatiga bisa berkembang maju sesuai dengan harapan.

Untuk harapan dalam pembelajaran di Jurusan KPI IAIN Salatiga, bagi MNA yaitu proses belajarnya lebih mengutamakan praktik dari pada teori. Menurutnya, KPI harus lebih banyak terjun lapangan, contohnya menjadi pendakwah di pengajianpengajian dalam masyarakat. Tidak semua orang bisa melakukan dakwah dengan profesional.

Proses pembelajaran di Jurusan KPI, PM berharap seluruh dosen selalu hadir dan tepat waktu, karena itu mempengarui sistem pembelajaran. Apabila memberi pengarahan atau pelajaran harus jelas, agar terbentuknya suasana pembelajaran yang efektif. Harapan PM setelah lulus dari KPI, adalah menjadi sebagai wartawan ataupun photografer, mengembangkan ilmu dan hobi, ditambah keyakinan untuk menghadapi masa depan sebagai tokoh masyarakat.

Harapan KAS dalam pembelajaran di KPI lebih ke praktikum daripada teori atau setidaknya seimbang antara teori dan praktikum. Dalam memacu kesungguhan belajar KAS akan membuktikan kepada orang-orang yang telah merendahkan masuknya KAS di Jurusan KPI IAIN Salatiga. Keyakinannya dalam menghadapi masa depan berkaitan dengan lulusan Komunikasi dan Penyiaran Islam, mendapatkan pekerjaan yang sesuai dengan kemampuannya. Bagi KAS realitas kadang tidak sesuai dengan latar pendidikan kadang tidak sesuai dengan dunia realitas profesi.

Harapkan RH dari pembelajaran di Jurusan KPI IAIN Salatiga adalah memberikan apa yang dibutuhkan dan bisa bermanfaat untuk dunia kerja nantinya, dengan diberikannya berbagai macam fasilitas kebutuhan seperti laboratorium penyiaran, studio, radio, komputer, untuk memacu kesungguhan belajar yang diperkuat oleh dosen yang professional.

Meskipun SW merasa kemampuan akademiknya di bawah kemampuan temantemannya yang lain, SW tetap berusaha dan memulai masa depan dengan penuh harapan, usaha serta doa. Agar ketika lulus dari KPI menjadi orang yang sukses di dunia kerja, memiliki agama yang kuat, selain agar mendapatkan ilmu yang bermanfaat. Berbeda dengan TA yang ingin mandiri, tidak ingin menyusahkan ibunya. Serta berkeinginan membahagiakan orang-orang terdekatnya. 
KPI adalah Jurusan baru secara otomatis mulai dari awal untuk mewujudkan Jurusan KPI menjadi lebih baik. TP berharap Jurusan KPI mempunyai peralatan untuk mengembangkan hobinya yaitu fotografer, belajar jadi seorang jurnalis. Sehingga TP berusaha untuk meningkatkan prestasi belajar, bukti tanggung jawab dan keharusannya sebagai seorang anak. Selain itu TP ingin membanggakan dan membahagiakan serta tidak ingin membuat orang tua dan keluarganya kecewa. TP yakin bisa sukses dengan berusaha dan berdoa, karana menurutnya Allah SWT akan memberi kemudahan dan jalan kepada orang yang sudah berusaha untuk mewujudkan apa yang orang itu inginkan.

Harapan $\mathrm{ZN}$ tidak jauh berbeda dengan mahasiswa KPI lainnya yaitu memiliki studio sendiri. Kesungguhan belajar $\mathrm{ZN}$ jelas terpacu pada impiannya, dan kondisi lingkungan akan sangat mempengaruhi kesungguhannya belajar. Pada lingkungan yang competitive $\mathrm{ZN}$ akan merasa dituntut untuk selalu belajar agar tidak tertinggal, namun di lingkungan yang minim sense of competitive akan sedikit membuat $\mathrm{ZN}$ bermalas-malasan. Dari situ $\mathrm{ZN}$ harus selalu mencari lingkungan yang competitive dengan etos kerja yang tinggi, karena itu akan sangat mempengaruhinya.

MR mengharapkan pembelajaran pada Jurusan KPI yang maksimal, khusunya dalam materi jurusan. Pembelajaran khusus materi jurusan tidak harus di dalam kelas, melainkan di luar kelas, seperti belajar di stasiun radio, stasiun televisi, kunjungan redaksi di harian surat kabar dan di production house. Harapan lain setelah lulus nanti, MR ingin membawa ilmu yang berlimpah, terutama ilmu yang sedang dipelajarinya di Jurusan KPI. Jika tidak bekerja, MR ingin mendirikan suatu produksi yang berhubungan dengan komuniksi.

Motivasi pada dunia pendidikan RS, carilah ilmu yang bisa kamu manfaatkan, dan mengikuti ajaran Rasulullah sebagai uswatun hasanah, intinya mengapa mencari ilmu banyak-banyak kalau tidak bisa memanfaakan atau membagi ilmu itu kepada orang yang belum tahu sama sekali. Bagi RS itu adalah percuma, tidak ada gunanya. Lebih baik mempunyai ilmu sedikit asal bisa bermanfaat. Harapan RS dalam pembelajaran di Jurusan KPI menjadi progam yang efektif, di dalam progam ini kalau dilihat banyak yang bisa mengembangkan bakat-bakatnya untuk menjadi pilihan terbaik. Keyakinan RS dalam menghadapi masa depan setelah lulus dari KPI nanti ialah, ingin sekali mengembangkan ilmu-ilmu yang sudah didapatkan dari bangku kuliah. 


\section{Antara Motivasi dan Eager Expectation Mahasiswa KPI IAIN Salatiga}

Motivasi secara etimologi berasal dari movere, yang berarti dorongan atau sokongan. Sementara secara epistimologi diartikan sebagai kekuatan yang terdapat dalam diri organisme yang mendorong untuk berbuat. Motif tidak berdiri sendiri, tetapi saling berkaitan dengan faktor-faktor lain, baik faktor eksternal, maupun faktor internal. Halhal yang mempengaruhi motif disebut motivasi. Motivasi adalah gejala psikologis dalam bentuk dorongan yang timbul pada diri seseorang secara sadar untuk melakukan suatu tindakan dengan tujuan tertentu. Motivasi juga bisa dalam bentuk usaha-usaha yang dapat menyebabkan seseorang atau kelompok orang tertentu tergerak melakukan sesuatu karena ingin mencapai tujuan yang dikehendakinya atau mendapat kepuasan dengan perbuatannya. Motivasi mempunyai peranan starategis dalam aktivitas belajar seseorang. Tidak ada seorang pun yang belajar tanpa motivasi, tidak ada motivasi berarti tidak ada kegiatan belajar. Agar peranan motivasi lebih optimal, maka prinsip-prinsip motivasi dalam belajar tidak hanya diketahui, tetapi juga harus diterangkan dalam aktivitas sehari-hari.

Abraham Maslow (1984:39) mengemukakan bahwa pada dasarnya semua manusia memiliki kebutuhan pokok. Ia menunjukkannya dalam 5 tingkatan hirarki yang berbentuk piramid, orang memulai dorongan dari tingkatan terbawah. Lima tingkat kebutuhan itu dikenal dengan sebutan Hirarki Kebutuhan Maslow, dimulai dari kebutuhan biologis dasar sampai motif psikologis yang lebih kompleks; yang hanya akan penting setelah kebutuhan dasar terpenuhi. Kebutuhan pada suatu peringkat paling tidak harus terpenuhi sebagian sebelum kebutuhan pada peringkat berikutnya menjadi penentu tindakan yang penting; Kebutuhan fisiologis (rasa lapar, rasa haus, dan sebagainya); Kebutuhan rasa aman (merasa aman dan terlindung, jauh dari bahaya); Kebutuhan akan rasa cinta dan rasa memiliki (berafiliasi dengan orang lain, diterima, memiliki); Kebutuhan akan penghargaan (berprestasi, berkompetensi, dan mendapatkan dukungan serta pengakuan); Kebutuhan aktualisasi diri (kebutuhan kognitif: mengetahui, memahami, dan menjelajahi; kebutuhan estetik: keserasian, keteraturan, dan keindahan; kebutuhan aktualisasi diri: mendapatkan kepuasan diri dan menyadari potensinya).

Sedangkan Mudjiono Dimyati (2010:80) menjelaskan bahwa ada tiga komponen utama dalam motivasi, yaitu; (1) kebutuhan, (2) dorongan, dan (3) tujuan. Kebutuhan terjadi bila individu merasa ada ketidakseimbangan antara apa yang dia miliki dan yang 
dia harapkan. Misalnya mahasiswa membutuhkan hasil yang baik. Maka mahasiswa tersebut mengubah cara-cara untuk mendapatkan apa yang ia butuhkan. Dorongan merupakan kekuatan mental untuk melakukan kegiatan dalam rangka memenuhi harapan atau pencapaian tujuan. Dorongan yang berorientasi pada tujuan tersebut merupakan inti motivasi. Tujuan adalah hal yang ingin dicapai oleh seorang individu.

Terdapat beberapa konsep motivasi. Konsep motivasi yang dijelaskan oleh Suwanto adalah sebagai berikut; Model tradisional; Model hubungan manusia; Model sumber daya manusia. Sementara menurut jenisnya motivasi terbagi; Motivasi Intrinsik, yaitu motif-motif yang menjadi aktif atau berfungsinya tidak perlu dirangsang dari luar, karena dalam diri setiap individu sudah ada dorongan untuk melakukan sesuatu. Sebagai contoh dalam penelitian ini seseorang mahasiswa yang berniat berkuliah di Jurusan KPI atas keinginan dan kesadarannya sendiri, maka dalam menjalankannya pun akan merasa yakin dan tanpa ada kekhawatiran. Kemudian kalau dilihat dari segi tujuan kegiatan yang dilakukannya, misalnya kegiatan kuliah, maka yang dimaksud dengan motivasi intrinsik ini adalah ingin mencapai tujuan yang terkandung di dalam perkuliahan itu sendiri. Kemudian motivasi ekstrinsik, yaitu motif-motif yang aktif dan berfungsinya karena adanya perangsang dari luar. Sebagai contoh seorang mahasiswa yang sekarang belajar di Jurusan KPI, akan merasa terpaksa dan menjalaninya terasa berat atau dalam keadaan bingung karena bukan didasarkan pada keinginan diri sendiri dalam pengambilan jurusan. Oleh karena itu motivasi ekstrinsik dapat juga dikatakan sebagai bentuk motivasi yang didalamnya aktivitas dimulai dan diteruskan berdasarkan dorongan dari luar yang tidak secara mutlak berkaitan dengan aktivitasnya.

Teori pengharapan dikemukakan oleh Victor H. Vroom (dalam Sudrajat, 2008:9) yang menjelaskan bahwa motivasi merupakan akibat suatu hasil dari yang ingin dicapai seseorang dan perkiraan yang bersangkutan bahwa tindakannya akan mengarah kepada hasil yang diinginkannya itu. Artinya, apabila seseorang sangat menginginkan sesuatu, dan jalan tampaknya terbuka untuk memperolehnya, yang bersangkutan akan berupaya mendapatkannya. Secara sederhana, teori harapan ini berkata bahwa jika seseorang menginginkan sesuatu dan harapan untuk memperoleh sesuatu itu cukup besar, yang bersangkutan akan sangat terdorong untuk memperoleh hal yang diinginkannya itu. Sebaliknya, jika harapan memperoleh hal yang diinginkannya itu tipis, maka motivasinya untuk berupaya akan menjadi rendah. 
Vroom (1964:175) tentang cognitive theory of motivation menjelaskan mengapa seseorang tidak akan melakukan sesuatu yang ia yakini ia tidak dapat melakukannya, sekalipun hasil dari pekerjaan itu sangat dapat ia inginkan. Menurut Vroom, tinggi rendahnya motivasi seseorang ditentukan oleh tiga komponen, yaitu; Ekspektasi (harapan) keberhasilan pada suatu tugas; Instrumentalis, yaitu penilaian tentang apa yang akan terjadi jika berhasil dalam melakukan suatu tugas (keberhasilan tugas untuk mendapatkan outcome tertentu); Valensi, yaitu respon terhadap outcome seperti perasaan posistif, netral, atau negatif. Motivasi tinggi jika usaha menghasilkan sesuatu yang melebihi harapan. Motivasi rendah jika usahanya menghasilkan kurang dari yang diharapkan. Dalam kehidupan organisasional disadari dan diakui bahwa kehendak seseorang ditentukan pula oleh berbagai konsekwensi ekstrernal dari perilaku dan tindakannya. Artinya, dari berbagai faktor di luar diri seseorang turut berperan sebagai penentu dan pengubah perilaku, sesuai dengan teori penguatan dan modifikasi Perilaku.

Dalam konteks hari ini, terdapat juga motivasai mahasiswa Jurusan Komunikasi dan Penyiaran Islam (KPI) IAIN Salatiga yang paling sederhana atau motif karena mengisi kekosongan yang penting kuliah tidak peting jurusannya, cukup banyak terdapat mahasiswa secara umum dan bukan saja terjadi pada mahasiswa dengan pilihannya pada Jurusan KPI. Realitas ini bukan terjadi tanpa motif dan harapan belaka.

\section{Simpulan}

Perkembangan Institut Agama Islam Negeri (IAIN) Salatiga dapat dirasakan secara nyata. Selain penguatan dalam basis keilmuan, penguatan infrastrukur terus digerakan secara optimal. Perlahan tapi pasti adalah realitas yang menjadi nyatanya usaha untuk terus mengembangkan kearah yang lebih luas. Perluasan itu terbukti dengan dibukanya beberapa jurusan guna memenuhi persyaratan alih status tersebut. Jurusan baru yang saat ini terbentuk adalah Jurusan Sejarah Kebudayaan Islam, Jurusan Pendidikan Guru Raudlatul Atfhal, Jurusan Ilmu Al-Quran dan Tafsir, serta Jurusan Komunikasi dan Penyiaran Islam.

Terdapat motivasi yang beragam pada mahasiswa Jurusan KPI IAIN Salatiga. Motivasi pembelajaran misalnya karena kemauan sendiri, masukan dari keluarga terdekat, sampai pada motivasi mengisi kekosongan, dari sekedar menganggur. Motivasi sendiri misalnya kuliah di Jurusan KPI tersebut adalah pilihannya sendiri. Bagi mahasiswa KPI yang lain merasa ada keterpaksaan, karena tidak diterima di salah satu 
perguruan tinggi yang mereka harapkan atau bahkan karena tidak diterima di Jurusan lain dalam kampus IAIN Salatiga. Mengenai eager expectation atau harapan besar mahasiswa Jurusan KPI IAIN Salatiga, terbagi pada beberapa pengharapan; Pengharapan dari proses dan pembelajaran sampai materi pendukung dari proses pembelajaran tersebut, hingga harapan masa depan mereka pasca lulus dengan menjadi sarjana komunikasi dan penyiaran terhadap lapangan kerja. Harapan dalam proses pengajaran atau pendidikan misalnya, sebagian mahasiswa Jurusan KPI IAIN Salatiga adalah peralatan-peralatan yang berkaitan dengan teknologi komunikasi dan teknologi penyiaran. Seperti kamera, handycamp, stasiun radio, dan lain sebagainya. Sementara harapan pasca selesai kuliah mereka banyak yang ingin menjadi orator handal, photographer, penyiar radio, guru, PNS, dan lain sebagainya.

\section{Daftar Pustaka}

Crow, L dan A. Crow. 1989. Psychology Pendidikan. Yogyakarta: Nurcahaya.

Dimyati, Mudjiono. 2010. Belajar dan Pembelajaran. Jakarta: Rineka Cipta.

Djamarah, Syaiful Bahri. 2000. Psikologi Belajar. Jakarta: Rineka Cipta.

Dodd, Carley H. 1982. Dynamics of Intercultural Communication. Dubuque: Wm. C. Brown Company Publishers.

Kcok, Heinz. 1991. Saya Guru yang Baik. Yogyakarta: Kanisius.

Maslow, Abraham. 1984. Motivasi dan Kepribadian. Jakarta: Gramedia.

Rusyan, Tabrani, dkk. 1989. Pendekatan dalam Proses Belajar Mengajar. Bandung: Remaja Rosdakarya.

Stephen P. Robins-Timothy A. Judge. 2008. Buku 1 Perilaku Organisasi; Organizational Behavior, Jakarta: Salemba Empat

Syamsuri. Mukh. 2010. Kamus Pintar Memilih Kata Bahasa Inggris, Jakarta: PT Gramedia Pustaka Utama

Sardiman A.1990. Interaksi dan Motivasi Belajar Mengajar. Jakarta: Rajawali Pers.

Suryabrata, Suryadi. 1984. Psikologi Pendidikan. Jakarta: Rajawali Press.

Syah, Muhibbin. 2002. Psikologi Pendidikan dengan Pendekatan Baru. Bandung: Remaja Rosdakarya.

Tadjab. 1994. Ilmu Pendidikan. Surabaya: Karya Abditama. 